\begin{tabular}{|c|c|c|c|c|c|c|}
\hline \multirow{4}{*}{ Impact Factor: } & ISRA (India) & $=3.117$ & SIS (USA) & $=0.912$ & ICV (Poland) & $=6.630$ \\
\hline & ISI (Dubai, UAE & $=0.829$ & РИНЦ (Russia & $=0.156$ & PIF (India) & $=1.940$ \\
\hline & GIF (Australia) & $=0.564$ & ESJI (KZ) & $=8.716$ & IBI (India) & $=4.260$ \\
\hline & JIF & $=1.500$ & SJIF (Morocco & $=\mathbf{5 . 6 6 7}$ & OAJI (USA) & $=0.350$ \\
\hline
\end{tabular}

\begin{tabular}{|c|c|}
\hline $\begin{array}{l}\text { SOI: } \frac{1.1 / \mathrm{TA}}{} \\
\text { International Sc } \\
\text { Theoretical \& A }\end{array}$ & $\begin{array}{l}S \text { DOI: } 10.15863 / T A S \\
\text { ientific Journal } \\
\text { pplied Science }\end{array}$ \\
\hline p-ISSN: 2308-4944 (print) & e-ISSN: 2409-0085 (online) \\
\hline Year: 2019 & Volume: 72 \\
\hline Published: 30.04 .2019 & http://T-Science.org \\
\hline
\end{tabular}

SECTION 31. Economic research, finance, innovation, risk management
QR - Issue

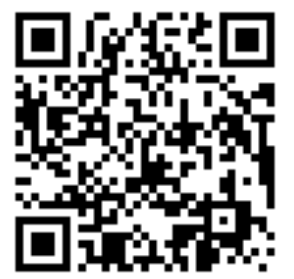

\title{
IMPROVING THE MECHANISMS OF USING INTERNAL INVESTMENTS IN THE NATIONAL ECONOMY
}

\begin{abstract}
The article considers the mechanism of using the investment potential in the national economy. In addition, the author also considers the determination of the boundaries of the inter-sectoral distribution of investments, the improvement of the inter-sectoral distribution of investments, as well as the analysis of the optimal boundaries of the distributed inter-sectoral investments in the Republic of Uzbekistan.

Key words: investment, domestic potential, GDP, inter-industry investment, investment attractiveness.

Language: English

Citation: Aymuhamedova, A. K. (2019). Improving the mechanisms of using internal investments in the national economy. ISJ Theoretical \& Applied Science, 04 (72), 467-475.

Soi: http://s-o-i.org/1.1/TAS-04-72-59 Doi: crossef https://dx.doi.org/10.15863/TAS.2019.04.72.59
\end{abstract}

\section{Introduction}

World experience shows that many countries have different approaches to the regional deployment and socioeconomic development of the regions, but they are almost no different from each other. It is particularly noteworthy that the search for the optimal mechanism for attracting foreign direct investment is one of the most rapidly developing and transition economies in a relatively short period of time. Unlike the developed countries, the experience of these countries shows that they have achieved remarkable results as a result of their investment policy, which is closer to Uzbekistan than ever before.

\section{THE EXPERIENCE OF FOREIGN COUNTRIES FOR INVESTMENTS IN THE REGIONS OF ECONOMY AND USING EFFECTIVE USE}

The goals of implementing regional economic policies in a number of countries are aimed at addressing the following objectives:

- Ensuring economic growth in developing countries;

- Install the majority of the functions of the central authorities in the local government system;

- limiting the accumulation of industrial production in major cities;

- Encouraging labor productivity and production development in newly acquired areas. One of the most popular ways to implement a rational investment policy is to set up regional development funds. For example, in 1975 the European Union established a regional coordination body. In other countries, special funds for the solution of socio-economic problems of some regions (Southern Treasury, which operates under the state subsidy in Italy and aimed at the development of southern regions infrastructure, in the implementation of the State Program for Accelerated Development of Certain Territories in Bulgaria the Fund for the Development of Regional Targeted Funds in Central Asia, and others). [1]

An important feature of many foreign countries' regional policies is that they are large administrativeterritorial units, not governors, states, provinces, and regional coordination bodies of cities and municipalities. These include nine agglomerations in France, less developed in France, 17 cities, 10 'development centers' in Spain and 2' industrial incentive centers', 10 'industrial areas in Japan' and 6 ' New Industrial Cities ", 12" Industrial Development Areas "in Italy and 26" Indus-Tria Leasing Nuclei "in Germany, 300 Population Cities in Germany, etc. The experience of the Netherlands and Belgium is particularly striking. It should be noted that the law on territorial development of cities and villages was first adopted in 1915 in Belgium. In many countries of the world, the investment policy can be applied differently depending on the domestic capacities and conditions of each region. The model of economic 


\begin{tabular}{|c|c|c|c|c|c|c|}
\hline \multirow{4}{*}{ Impact Factor: } & ISRA (India) & $=3.117$ & SIS (USA) & $=0.912$ & ICV (Poland) & $=6.630$ \\
\hline & ISI (Dubai, UAE & $=0.829$ & РИНЦ (Russia) & $=0.156$ & PIF (India) & $=1.940$ \\
\hline & GIF (Australia) & $=0.564$ & ESJI (KZ) & $=8.716$ & IBI (India) & $=4.260$ \\
\hline & JIF & $=1.500$ & SJIF (Morocco & $=5.667$ & OAJI (USA) & $=0.350$ \\
\hline
\end{tabular}

development of the People's Republic of China and the experience of attraction of foreign investments are of special importance for Uzbekistan. This feature of China's socioeconomic development is characterized by the specificity of the democratic situation in it, its high economic importance in the economy, the lack of processing industry, its specific social conditions, such as the agrarian-industrial country. This country's foreign investment The success of the project is largely dependent on the creation of a favorable investment environment in its regions. The low cost of labor in the XI, the wide use of land, the wide range of privileges for the cotton industry, the development of social infrastructure, and many other things have led to the fact that this country has become an investment destination for foreign investors in recent years. , advanced foreign economic relations and foreign exchange legislation have created favorable conditions for foreign investment. Attracting voluntary investments into the regional economies of China policy has been improving over the years. The development of this policy can be divided into three stages on the contingent. 2 The first stage involves the years 1979-1982. At this stage, the "open door" policy has emerged in China. In the early 1980s, local governments were granted the right to make decisions on the attraction of foreign investments. During this period, foreign investors were given great benefits. The second phase included 1983-1991. During this period, the policy of attracting foreign investment was improved. In the country's laws and regulations, the companies with foreign investments were given substantial benefits. Their income tax rate was reduced to $33 \%$. Meanwhile, income tax for local businesses was 55 percent. If enterprises with venture capital are operating in special economic zones, this rate has been set at less than $15 \%$. The third stage has continued since 1992. [3]

The attraction of foreign investments to the economy, which was closed to them - financial, insurance and other sectors - began in 1992. As a result of such effective reforms, China has become one of the most attractive countries for foreign investment at the beginning of the 21 st century. The Japanese experience in this field has particular advantages. As a result of the consistent implementation of the socio-economic development programs of the long-term targeted regions, Japan has historically been short-sighted 2 Rustamova D.D. The rationale and priorities of attracting foreign investments in the context of economic liberalization are one of the most developed countries in the world. Japan's regional investment policy is based on the need for land and natural resources restriction, the need to adapt human activities to natural conditions, and the need to reduce the living standards of people in different parts of the country. Developing regional investment programs at every stage of socio-economic development of the country is determined based on the goals and objectives facing the society and the state, and their capacity and capabilities. In Japan, flexible and convenient methods of attracting investments and production capacities to less developed regions are used. The dynamic investment policy, first of all, must meet the internal and external requirements of the modern world. In the 80-90's of the XX century, the largest scale of these products was globalization. In the $80-90$ 's of the XX century, goods and stock markets, labor markets, development institutions, production and logistics systems, intellectual property rights (intellectual property rights, TRIPS, 1995). Globalization is an important consequence of global "tectonic" shifts. The essence of these movements is that China and India are increasingly exposed to their influence on these processes. Such factors as the longterm growth of high rates of economic growth, the enlargement of military capabilities, the rapid deployment of high technologies, and the rapid growth of the population make it possible to increase the economic and political power of these countries. In China, investment policy reforms and market mechanisms are being implemented at various stages of economic development, while the management methods have been used more frequently in the "hot" phase of the economy. China's "economic growth" is based on several key factors: reforming agriculture, reducing taxes, reducing public spending, and creating free economic zones (liberalizing exports). [2]

The Chinese administration has yet to abolish unpaired tax policy in the world economic practice from 30.4 percent in 1979 to GDP in 1979 , to 10.3 percent in 1996. This did not lead to adverse macroeconomic consequences, as at the same time, all government spending decreased from $36.4 \%$ to $13.1 \%$. One of the instruments of Chinese investment policy is taxation. With this tool, the government struggled against the growth of capital construction. However, if businesses purchase equipment from the domestic market for technological modernization, they will be able to enjoy the privilege of up to $40 \%$ of the gross premiums. In the late $90 \mathrm{~s}$ of the 20th century, when the GNP growth rates declined, the government required the Treasury has started to stimulate investment activity through issuing emissions. During the period of 1998-2002, the volume of this vehicle was 80.5 billion. These funds were used for the construction of irrigation facilities, highways, airports, storage facilities, forestry and partial modernization of state-owned enterprises. The Indian investment policy efficiency was the highest index of global competitiveness of 4.1 (Egypt, Khorva the Czech Republic and the Czech Republic), and also indicates a significant improvement in the export structure, which accounts for 3/4 of finished products over the past few years. Some indicators of economic and investment activity India occupies one of the leading positions among the world's developing countries. The average growth rate of GDP for the 


\begin{tabular}{|c|c|c|c|c|c|c|}
\hline \multirow{4}{*}{ Impact Factor: } & ISRA (India) & $=3.117$ & SIS (USA) & $=0.912$ & ICV (Poland) & $=6.630$ \\
\hline & ISI (Dubai, UAE & $=0.829$ & РИНЦ (Russia) & $=0.156$ & PIF (India) & $=1.940$ \\
\hline & GIF (Australia) & $=0.564$ & ESJI (KZ) & $=8.716$ & IBI (India) & $=4.260$ \\
\hline & JIF & $=1.500$ & SJIF (Morocco) & $=5.667$ & OAJI (USA) & $=0.350$ \\
\hline
\end{tabular}

years 2000-2004 (compared to 4.5 per cent of the world's average developed economies) was 5.7 per cent, while the gross investment (by 5.2 per cent) was 7.7 per cent. one of them is a carefully thought out investment policy focused primarily on activating internal sources of economic development. This is illustrated by gross domestic savings (21.6\% of GDP over the last 5 years), gross investment (22.5\%). These indicators make up $18.6 \%$ and $20.9 \%$ respectively for the developing world countries.

The following sectors are prioritized in the investment of sectors and sectors of the economy: non-resource sectors of industry; nobank financial services; foodstuffs production; Infrastructure construction of highways, harbors, power plants, mass-speed transport systems; civil aviation, medicine and pharmacy; hotel business and tourism; electronic equipment and software; private oil refineries; exploration and production of mineral raw materials; consulting services, etc. The size of foreign investments on joint stock companies for small businesses is subject to special restrictions. The share of these enterprises in the authorized capital is $24 \%$ of foreign participation. When foreign participation exceeds this level, the venture must obtain a production license for compulsory export of $50 \%$ of the product. India has established international and bilateral agreements with many countries on investment promotion and protection. [11] These transactions allow for free movement and return of investments; nationalization, if they do not contradict the national interests of the country. Chile is a platform for investments in the region and beyond. The platform was proposed by the Committee for Foreign Investments of Chile in 2002 and has been implemented since then. Chile is a country that has achieved success in improving national economic competitiveness. In the Global Competitiveness Index (4.9), the country ranks the world's most advanced developing countries in 2006 (higher than Malaysia and slightly less than Israel) and overtook all Latin American countries. Positive international ratings, high ratings of investment climate, politics and the choice of government's liberalization of economic life have a positive impact on foreign investors. It has been in use since 1947 to regulate the activities of foreign investors in the country passing Decree-law will serve as a basis for foreign investors. It is one of the most advanced documents in the world on guarantees of foreign capital protection. According to the Decree Law, investors have the right to repatriate the benefits provided to the national regime and, since 2000, there are no fixed capital restrictions. Most foreign investors prefer to work on the principles of this document: from 1974 to 2004, over $80 \%$ of investments were made in Chile. According to the Decree-Law, any foreigner legal entities and individuals, as well as Chileans living abroad, have the right to invest in the country. Unlike most Latin
American countries, all areas for foreign and private investment are provided in Chile. Except for air transport and the media, Thailand is in the process of liberalizing the economy (focusing on the banking sector and foreign trade), strengthening macroeconomic stability, investment priorities, transparency in privatization, and granting privileges and preferences.

The measures taken in this country in the past few years will allow to simplify the process of expanding the scope of foreign direct investment, the investment climate, the facts and methods of taxation, and various incentives and preferences. This includes simultaneous repatriation of profits, repatriation of profits of foreign investors, improvement of the legal norms creating a positive image of the country (organization of exhibitions, invitation of investors and journalists, special publications of investors), foreign offices of the National Council, such as public disclosure and publication of national priorities. For example, in 2002, the focus was on modern agrotechnology, clothing, jewelry, automobiles and new tourism technology. As a result, Thailand has progressed from many emerging economies in terms of economic liberalization (Index of Economic Freedom for Developing Countries in 2000-2004 66.6 percent compared to 57.5 percent, macroeconomic stability index - GDP deflator 1.8 percent compared to 8.2 percent, modernization of the economy the index of recovery was 97.7 percent versus 48.6 percent). The Thai example highlights the importance of the banking sector to increase the efficiency of investment policy. Even in the case of developing countries, the banking sector can simultaneously involve a portion of the income of the population and entrepreneurship, thereby improving the level of macroeconomic stability and improving the investment environment by attracting economically active population and private businesses. Despite the differences and specificity of the investment policies of countries (China, India, Chile), the overall investment strategies and mechanisms of these countries y parties. [3,4]

These are:

1. The role of the state is high when organizing an effective investment policy (especially at its stages). At the same time, the functions of the state are not limited to the creation of a favorable investment climate, attracting foreign investment, developing infrastructure networks, creating and maintaining the necessary regulatory and legal framework. It is important to address such issues as development of human and social capital, strengthening the institutional capacity of the state institutions, and increasing the investment in the development of new innovative sectors of the economy. At the same time, with the deepening of liberalization processes, the scope of direct regulation of the investment processes on the part of the government has diminished, and the 


\begin{tabular}{|c|c|c|c|c|c|c|}
\hline \multirow{4}{*}{ Impact Factor: } & ISRA (India) & $=3.117$ & SIS (USA) & $=0.912$ & ICV (Poland) & $=6.630$ \\
\hline & ISI (Dubai, UAE & $=0.829$ & РИНЦ (Russia) & $=0.156$ & PIF (India) & $=1.940$ \\
\hline & GIF (Australia) & $=0.564$ & ESJI (KZ) & $=8.716$ & IBI (India) & $=4.260$ \\
\hline & JIF & $=1.500$ & SJIF (Morocco & $=5.667$ & OAJI (USA) & $=0.350$ \\
\hline
\end{tabular}

functions of stimulating investment flows indirectly are becoming increasingly important.

2. Favorable and strong investment climate that promotes direct foreign investment. This will ensure that the level of savings will not be less than 20 per cent of GDP, and that the growth rates of investment are higher than GDP growth rates (2-4 points). The final indicator is made at the expense of private investments. At the same time, large amounts of loans to the private sector (Thailand, India), the combination of free market forces and government active roles in addressing social and economic problems (low inflation, job creation, poverty reduction, etc.) The

3. Sustainable development of the banking sector and the financial market. The level of monetization in many of the world's most competitive countries is over 50 percent. Only then will there be created conditions for the use of free resources of the population and entrepreneurs, the efficiency of the use of investment resources, and the effective anti-inflation policy. Integrity and integrity of investment policy. As you know, the investment policy is one of the key components of the country's economic development strategy (eg, India's new policy, Thailand's industrial policy, Chile's export potential development policy) and nationwide benefits. In particular, the Chinese investment policy is an effective tool for regulating cycles, ensuring sustainable development, maintaining high growth rates (taking into account the cyclical development of China economy). Increasing the quality of public institutions responsible for investment policy. It involves the involvement of independent experts (prominent scientists and prestigious entrepreneurs) into the governing boards and structures that distribute public resources. These resources are provided for the formation of the starting capital of private investment and innovation funds as the state support for these or other investment projects. For this purpose, the government used private lowprofit corporations, dealing with government contracts. Transparency of investment incentives and preferences in these countries plays an important role. Orientation of capital flows to the development of high technology. Many developing countries have used development strategies to help them to overcome differences in economic development with developed countries. The main mechanism is public-private partnership, risk sharing between government and business, state co-financing costs for marketing research, staff training, and new product certification. [4]

4. Giving priority to investment in human and social capital. The need to ensure the growth of competitiveness in a fast-paced economic environment creates a distinct priority for developing countries in terms of attracting large-scale investments into human and social capital. Attention to the education sector has been the most important criterion for assessing the economic growth prospects of developing countries. The experience of foreign countries shows that not only investment incentives, but also investment promotion (investment promotion) ) strategies are also important. Research based on the experience of 50 industrialized and developing countries has shown that every dollar spent on investing in the capital can give a four-dollar effect to the national economy. Investments that are specifically targeted at one or another sector and designed for specific potential investors and have an active marketing strategy are most effective.

\section{INVESTMENT POSSIBILITIES OF INDUSTRIAL PROPERTY IN THE MODERNIZATION CASE OF THE NATIONAL ECONOMIC DEVELOPMENT OF UZBEKISTAN}

At the modern stages of the development of the national economy of Uzbekistan, the competition of entrepreneurs in the manufacturing sector is gaining momentum. Under such circumstances, production entrepreneurship plays an important role in the economy. In the implementation of the Anti-Crisis Program in 2010, one of the priorities is the accelerated modernization, technical and technological renovation of the most important sectors of the economy, the development of modern transport and infrastructure communications through attracting investments, primarily by using internal resources. $[5,6]$

It is well-known that some of the key directions identified in the Anti-Crisis Program for 2009-2012 are fold expansion of activities and ensure the growth of investment activity. The implementation of the program, more specifically, was summarized in 2009 by commercial banks for financing projects of modernization, technical and technological renovation, totaling 2.4 trillion soums in 2008 , and 1.6 times more investment loans, if compared to 2008 . In particular, in 2009, 690 investment projects were implemented within the framework of investment programs and technical modernization programs, of which 303 projects were successfully completed. Total volume of investments into the economy made up US $\$ 8.2$ billion in 2008 , by almost $24.8 \%$. The volume of attracted investments has increased by $68 \%$ and most of them are direct investments. For the full implementation of the Investment Program for 20092014 it is envisaged to allocate US $\$ 42.5$ billion from all financial sources. The highest level of investment programs in 2010 was accounted for by $42.6 \%$ of enterprises' funds, direct investments were made at the expense of $21.3 \%$. According to preliminary data, in 2010, commercial banks' loans and other borrowed funds and funds of the Development and Savings Fund accounted for $22.6 \%$ of all investment funds. The Decree of the President of the Republic of Uzbekistan " The adoption of the Resolution "On 


\begin{tabular}{|c|c|c|c|c|c|c|}
\hline \multirow{4}{*}{ Impact Factor: } & ISRA (India) & $=3.117$ & SIS (USA) & $=0.912$ & ICV (Poland) & $=6.630$ \\
\hline & ISI (Dubai, UAE & $=0.829$ & РИНЦ (Russia & $=0.156$ & PIF (India) & $=1.940$ \\
\hline & GIF (Australia) & $=0.564$ & ESJI (KZ) & $=8.716$ & IBI (India) & $=4.260$ \\
\hline & JIF & $=1.500$ & SJIF (Morocco & $=5.667$ & OAJI (USA) & $=0.350$ \\
\hline
\end{tabular}

Priority Areas of Development of the Republic's Industry" can be described as one of the vectors of the country's industrial potential mobilization. vojlantirishning target indicators, and prepared to carry out, or, as at present, including a list of investment projects carried out on the priorities of industrial development of Uzbekistan for 2011-2015 "program" to confirm. Over the past five years alone, 259 industrial projects have been planned to spend over $\$ 30$ billion. Within the framework of new construction, US $\$ 23.05$ billion will be spent. The modernization of existing enterprises will require 5,242 milliard dollars of capital investments, and \$ 1,783 billion for re-equipment of enterprises of different sectors. The program also includes 99 more projects. Their initial value is $\$ 6.446$ billion. Industry reform also includes 158 investment projects worth \$ 10.98 billion in fuel and energy, chemical, metallurgy, light industry, construction and machinery sectors.

Consideration of strategic results of small business (development, potential outcomes). The known bar codes are based on actual or expected actual results; the use of value-sized computing results that will help you get monomers that can lead to more targeted administration. This criterion should combine factors such as economic (budget revenues) and social (growth of wages, increase of workplaces). It is important to take into account the criteria for local performance indicators. The interest of subjects and of the region's administration to the development of entrepreneurship should be as diverse as the hierarchical system, depending on the situation in the region. In terms of strategic development of the region's economy and its manufacturing industries, the most cumulative investment projects, due to a combination of resources to support them, should be considered as the priority areas of government support. can participate in investment projects. Particular attention is paid to the assessment of the economic success and success of the so-called "people's interests". These are infrastructure projects; innovative projects with significant multiplicative effects. Here the first innovative solutions (and funds) are provided by private owners, and the state capital is a guarantee.

According to the State Statistics Committee of Uzbekistan, the volume of investment in agriculture and construction has been 10-15 times lower than in industrial and service sectors. The annual average value of investment in the economic sectors in 20002017 amounted to UZS 3893.5 bn. It is possible to identify a number of indicators for this situation.

In particular, a line chart on the circulation of investments in economic sectors is created. For this purpose, first of all, they are grouped according to their marginal values, using their fair values determined on the basis of annual dynamic indicators of the intersectoral distribution of investment. The goal is to calculate the set parameters for each set and set.

Table 1 below shows that the columns 2, 3 and 4 are divided by the average of the average annual investment values on the basis of the five conditions, representing a percentage of the total.

Table 1. Periodic distribution of investments in linear scales networks

\begin{tabular}{||l|c|c|c|c|c|l|}
\hline \hline \multicolumn{1}{|c|}{ T/p } & \multicolumn{2}{c|}{$\begin{array}{c}\text { Periodic amount of investments (UZS } \\
\text { bn) }\end{array}$} & Number of periods & Plot size \\
\hline \multicolumn{1}{|c|}{ T/p } & $\geq$ & $<$ & "from-too" & in unity & percent & percent \\
\hline very bad & 1 & 850 & $1-850$ & 6 & 33,3 & 5,9 \\
\hline bad & 850 & 1700 & $850-1700$ & 2 & 11,1 & 7,1 \\
\hline middle & 1700 & 3400 & $1700-3400$ & 2 & 11,1 & 16,7 \\
\hline good & 3400 & 6800 & $3400-6800$ & 4 & 22,2 & 33,1 \\
\hline very good & 6800 & 13600 & $6800-13600$ & 4 & 22,2 & 21,6 \\
\hline TOTAL ON TIME & & & 18 & 100 & 84,3 \\
\hline XI square meter comparison of real and normal distribution of investments & & $85,1 \%$ \\
\hline
\end{tabular}

Source: Development of the authors based on the data from the State Committee on Statistics of the Republic of Uzbekistan.

According to figures in Table 1, the most important is the 7th column, which sets out the distribution of investment by sectoral status. $27.4 \%$ and $4.0 \%$ of investments were allocated on the sectoral basis, while the third and fourth position was $5.6 \%$ and $10.9 \%$ less than the norm for the first and second cases. In the fifth case, 21.6 percent, instead of
22.2 percent, were found to be 0.6 percent higher than the norm, and a total investment of more than 15.7 percent of the investment needed to be allocated to the industry was calculated in the overall 2000-2017 years.

This, meanwhile, indicates that $15.7 \%$ of investments have remained unprofitable. In general, 


\begin{tabular}{|c|c|c|c|c|c|c|}
\hline \multirow{4}{*}{ Impact Factor: } & ISRA (India) & $=3.117$ & SIS (USA) & $=0.912$ & ICV (Poland) & $=6.630$ \\
\hline & ISI (Dubai, UAE & $=0.829$ & РИНЦ (Russia & $=\mathbf{0 . 1 5 6}$ & PIF (India) & $=1.940$ \\
\hline & GIF (Australia) & $=0.564$ & ESJI (KZ) & $=8.716$ & IBI (India) & $=4.260$ \\
\hline & JIF & $=1.500$ & SJIF (Morocco & $=5.667$ & OAJI (USA) & $=0.350$ \\
\hline
\end{tabular}

the current situation in the current sector (especially 1 and 2 cases) has shown that the effectiveness of distributed investments is 155060,1 billion soums. 131491,0 billion sums, which is 14,0 percent less than the national currency. It could also be done in soum. According to the results of the calculations, the fact that the proportion of investment in $100 \%$ is actually $84.3 \%$. [7]

Investments play an important role in supporting and enhancing the economic potential of the country, modernization and diversification of the economy, activating economic growth, increasing the competitiveness of products and services both at home and abroad. Investments lead to growth of GDP, the development of enterprises and the export potential of the country.

It is necessary to develop a regional investment policy to address the issue of attracting investments into the region's economy. Regional investment policies are the activities of the regional administration, which should be sought from sources of investment and directed to the most effective sectors.

The purpose of investment policy can be explained by:

1. Implementation of structural changes, development of priority sectors.

2. Support for small business and private entrepreneurship.

3. Creating additional jobs.

4. Attracting investment resources from all sources. At the same time, attracting foreign investment.
5. Creation of non-state investment funds, as well as venture funds.

6. Expansion of leasing activity in innovation activity.

7. Improve the system of privileges.

8. Ensuring investment climate and attractiveness.

The analysis of these areas is one of the most pressing issues of today. [8]

In the strategic context of the country, achieving a balanced regional socio-economic development is crucial to ensuring macroeconomic stability and proportional economic growth. The existence of an asymmetric distinction in the current socio-economic development requires the implementation of an active regional investment policy aimed at the efficient use of existing economic and resource potential and the revitalization of economic development in relatively less developed regions. At the same time, there is a need to deepen reforms to revitalize investment activity based on proper valuation and management of regional financial and investment capacities.

The Strategic Action Strategy for the five main priorities of the Republic of Uzbekistan for 2017-2021 is to implement the tasks in the near future "to improve the investment climate, to actively attract foreign, primarily direct foreign investment in the sectors and regions of the country's economy."

In 2019, the President's Address to the Parliament on the most important priorities of the country's development in 2019 was named the Year of Active Investments and Social Development, and identified important goals for economic reform.

Table 2. Investments into fixed capital and their distribution in Uzbekistan, bn. soums

\begin{tabular}{|c|c|c|c|c|c|c|c|}
\hline \multirow[t]{2}{*}{ Name of Regions } & \multicolumn{6}{|l|}{ Years } & \multirow{2}{*}{$\begin{array}{l}\text { Increasing by } \\
2018 \text {, compared } \\
\text { to } 2013\end{array}$} \\
\hline & 2013 & 2014 & 2015 & 2016 & 2017 & 2018 & \\
\hline Total in the country & 28694,6 & 35233,3 & 41670,5 & 49770,6 & 60719,2 & 107333,0 & 374,1 \\
\hline $\begin{array}{l}\text { Republic } \\
\text { Karakalpakstan }\end{array}$ & 2361,9 & 3917,8 & 5925,7 & 3718,9 & 2235 & 6046,4 & 256,0 \\
\hline Andijan region & 1287,8 & 1423 & 1661 & 1987,3 & 2236 & 4056,0 & 315,0 \\
\hline Bukhara Region & 2871,6 & 3408,3 & 3866,1 & 5756,7 & 11008,9 & 7846,1 & 273,2 \\
\hline Jizzakh Province & 1017,9 & 1038,5 & 1101,1 & 1247 & 1436,7 & 3169,2 & 311,3 \\
\hline Kashkadarya Province & 3498,8 & 4483,2 & 5590,5 & 7048,8 & 10181,9 & 15321,1 & 437,9 \\
\hline Navoi Province & 1622,6 & 1653 & 1685,4 & 2846,8 & 2784,5 & 10059,1 & 619,9 \\
\hline The Namangan Region & 1059,3 & 1618,7 & 1966,4 & 2566,7 & 3052 & 7131,0 & 673,2 \\
\hline Samarkand Region & 1915 & 2247,8 & 2854 & 3321,4 & 3307,1 & 5746,9 & 300,1 \\
\hline Surkhandarya region & 1246,8 & 1339,5 & 1633,4 & 2005,2 & 2949,1 & 6111,0 & 490,1 \\
\hline Syrdarya region & 804,7 & 927,2 & 1000,2 & 1240,9 & 1349,4 & 2154,6 & 267,8 \\
\hline Tashkent region & 2982,9 & 3741,9 & 4055,7 & 3959,9 & 4301,8 & 9351,4 & 313,5 \\
\hline Fergana Province & 1899,7 & 1998,4 & 2133 & 2404,5 & 2473,8 & 4978,4 & 262,1 \\
\hline Khorezm Region & 1148,5 & 1466,5 & 1343,4 & 1445,4 & 1877,1 & 2980,0 & 259,5 \\
\hline
\end{tabular}




\begin{tabular}{|c|c|c|c|c|c|c|}
\hline \multirow{4}{*}{ Impact Factor: } & ISRA (India) & $=3.117$ & SIS (USA) & $=0.912$ & ICV (Poland) & $=6.630$ \\
\hline & ISI (Dubai, UAE & $=0.829$ & РИНЦ (Russia) & $=0.156$ & PIF (India) & $=1.940$ \\
\hline & GIF (Australia) & $=0.564$ & ESJI (KZ) & $=8.716$ & IBI (India) & $=4.260$ \\
\hline & JIF & $=1.500$ & SJIF (Morocco) & $=5.667$ & OAJI (USA) & $=0.350$ \\
\hline
\end{tabular}

\begin{tabular}{|l|l|l|l|l|l|l|l|}
\hline City of Tashkent & 4977,1 & 5969,5 & 6854,6 & 10221,1 & 11525,9 & 21861,5 & 439,2 \\
\hline
\end{tabular}

Source: the author's calculations based on the data from the Statistics Committee of the Republic of Uzbekistan.

In 2019, Uzbekistan plans to invest about 138 trillion soums or $16 \%$ more than in 2018 . The volume of direct foreign investments in this area has increased by almost 1.5 times compared with the current year and reached 4.2 billion dollars, as a result of which it is planned to put into operation 142 modern enterprises.

Consistent implementation of regional economic policy on these tasks, in the future, constitutes the fundamental basis for determining the strategic directions of regional investment policy.

Table 1 shows that capital investments in the Republic are estimated at UZS 28694.6 bn. This figure was characterized by steady growth and amounted to 107333.0 billion soms by 2018. soums. Thus, the growth of nominal value of fixed capital investments in these years was 3.7 times. [9]

Investment in fixed capital in Uzbekistan in 2018 grew by $374.1 \%$ compared to 2013 . High growth rates are observed in Kashkadarya (437.9\%), Namangan (673.2\%), Navoi (619.9\%) and Surkhandarya $(490.1 \%)$ provinces and Tashkent city $(439.2 \%)$.
The role and significance of investment in fixed capital in the socio-economic development of the regions can be explained by:

First of all, the growth of investment in fixed capital will have a positive impact on the annual growth rate of GRP as a factor of high technological advancement and intensive economic growth; [12]

Secondly, the diversification of the economy, the implementation of structural reforms will ultimately provide for the establishment of import-substituting and export-oriented products;

Thirdly, it promotes the development of entrepreneurship in the context of rational use of existing financial and investment capacities and ultimately increases the well-being of the population through the creation of new jobs. As a result, the expansion of the aggregate demand in the economy, thanks to consistent growth of the population's income, creates conditions for the further development of production. [10]

It is possible to identify the investment activity of each region by means of the average national cumulative nominal amount of investment in fixed capital.

Table 2. Share of Regions in Capital Investments in Uzbekistan (\% of total)

\begin{tabular}{|l|l|l|l|l|l|l|}
\hline \multirow{2}{*}{ Regions } & \multicolumn{5}{c|}{ Share of regions in main capital investments, \% } \\
\cline { 2 - 6 } & 2013 & 2014 & 2015 & 2016 & 2017 & 2018 \\
\hline Total in the country & 100 & 100 & 100 & 100 & 100 & 100 \\
\hline Republic of Karakalpakstan & 8,23 & 11,12 & 14,22 & 7,47 & 3,68 & 5,6 \\
\hline Andijan region & 4,49 & 4,04 & 3,99 & 3,99 & 3,68 & 3,8 \\
\hline Bukhara Region & 10,01 & 9,67 & 9,28 & 11,57 & 18,13 & 7,3 \\
\hline Jizzakh Province & 3,55 & 2,95 & 2,64 & 2,51 & 2,37 & 3 \\
\hline Kashkadarya Province & 12,19 & 12,72 & 13,42 & 14,16 & 16,77 & 14,3 \\
\hline Navoi Province & 5,65 & 4,69 & 4,04 & 5,72 & 4,59 & 9,4 \\
\hline The Namangan Region & 3,69 & 4,59 & 4,72 & 5,16 & 5,03 & 6,6 \\
\hline Samarkand Region & 6,67 & 6,38 & 6,85 & 6,67 & 5,45 & 5,4 \\
\hline Surkhandarya region & 4,35 & 3,8 & 3,92 & 4,03 & 4,86 & 5,7 \\
\hline Syrdarya region & 2,8 & 2,63 & 2,4 & 2,49 & 2,22 & 2 \\
\hline Tashkent region & 10,4 & 10,62 & 9,73 & 7,96 & 7,08 & 8,7 \\
\hline Fergana Province & & & & & 4,83 & 4,07 \\
\hline Khorezm Region & 6,62 & 5,67 & 5,12 & 4,83 & 4,6 \\
\hline Tashkent city & 4 & 4,16 & 3,22 & 2,9 & 3,09 & 2,8 \\
\hline
\end{tabular}

Source: the author's calculations based on the data from the Statistics Committee of the Republic of Uzbekistan.

According to the Table 2, the highest level of capital investment in the country is in Tashkent. In particular, the share of Tashkent city in total fixed capital in 2013 amounted to $17.35 \%$, while the relative 


\begin{tabular}{|c|c|c|c|c|c|c|}
\hline \multirow{4}{*}{ Impact Factor: } & ISRA (India) & $=3.117$ & SIS (USA) & $=0.912$ & ICV (Poland) & $=6.630$ \\
\hline & ISI (Dubai, UAE & $=0.829$ & РИНЦ (Russia & $=\mathbf{0 . 1 5 6}$ & PIF (India) & $=1.940$ \\
\hline & GIF (Australia) & $=0.564$ & ESJI (KZ) & $=8.716$ & IBI (India) & $=4.260$ \\
\hline & JIF & $=1.500$ & SJIF (Morocco & $=5.667$ & OAJI (USA) & $=0.350$ \\
\hline
\end{tabular}

decline was observed in 2014 and 2015 , but by 2017 it was $18.98 \%$, and in 2017 it was $20.4 \%$. In the period under review, the highest growth was observed in Kashkadarya region (14.3\%), Tashkent region (8.7\%), and in 2018 it achieved the leading indicators (Table 2). However, in Syrdarya (2 percent), Khorezm (2.8 percent) and Jizzakh (3.0 percent) regions this indicator is relatively low.

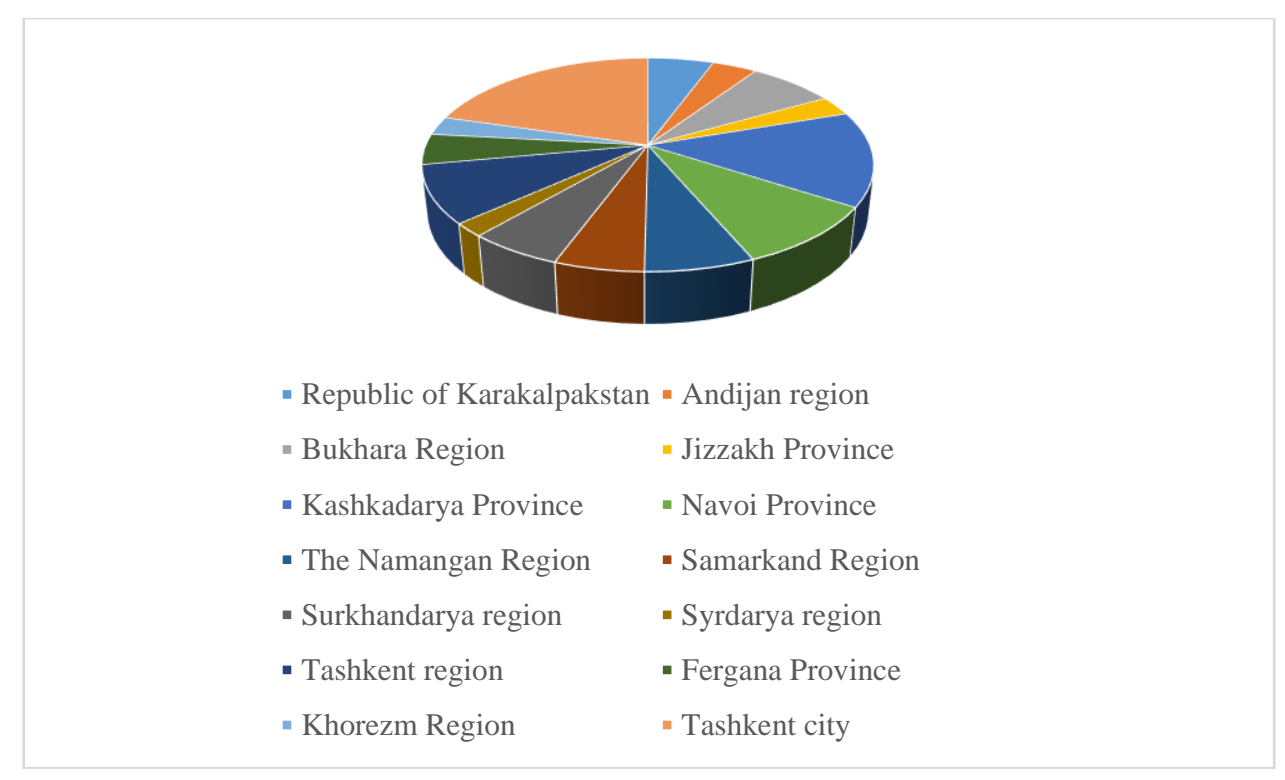

Fig. 1. Share of Regions in Capital Investments in Uzbekistan, 2018 (in \% of total) [13]

In the context of current reforms, the issue of increasing investment activity through the rational use of available financial and investment capacities in each region is becoming an urgent issue on the agenda.

Based on the above analysis, in our opinion, the opportunities for increasing investment activity in the regions of the Republic of Uzbekistan are as follows:

1. In order to carry out systematic work on territorial infrastructure and, in particular, investment infrastructure, it is necessary to modernize the road transport and communications system, carry out deep reforms in public utilities, introduce high-speed internet systems.

2. It is necessary to increase the volume of investments through the introduction of a long-term crediting system for poor regions. At the same time, the creation of potentially bank branches and minibanks, strengthening their capitalization and development of the financial infrastructure are especially important in the areas with insufficient investment resources. Development of modern forms of financial institutions such as investment and insurance funds, credit unions, pawnshops, bank groups and holdings, mutual funds accelerates capital movement in the economy.

3. Creating a systemized regional registry with detailed and detailed information on production facilities, existing natural resources, agricultural and raw materials resources in the regions of the Republic and the Internet for the purpose of forming a positive image of the regions and demonstrating an attractive investment climate in the world and in the Republic. it should be brought to the attention of foreign investors.

\section{Conclusion}

A comprehensive approach to the identification and regulation of investment opportunities in enterprises and regions can be achieved by formulating the necessary resources for investment resources and enhancing investment activity on the basis of effective utilization of in-venture funds .2. In Uzbekistan under current conditions, the growth and development of investment capacities of entrepreneurial entrepreneurship is linked with the need to overcome the deficit of investment resources in manufacturing. It is primarily dependent on the creation of an optimal investment mechanism for investment, and, on the other hand, the investment goods that are capable of offering high-quality investment products and the rational actions of the owners of the investment capital that will allow them to be bartered without any barrier in the investment market. In turn, increasing the efficiency of entrepreneurship at the state, republican, regional and local levels depends on the coordination of direct government support and coordination of state investment incentive activities. The first phase of the market regulation includes the transition from direct subsidies to targeted subventions, multi-subject financing of employment projects, which are of great 


\begin{tabular}{|c|c|c|c|c|c|c|}
\hline \multirow{4}{*}{ Impact Factor: } & ISRA (India) & $=3.117$ & SIS (USA) & $=0.912$ & ICV (Poland) & $=6.630$ \\
\hline & ISI (Dubai, UAE & $=0.829$ & РИНЦ (Russia) & $=0.156$ & PIF (India) & $=1.940$ \\
\hline & GIF (Australia) & $=0.564$ & ESJI (KZ) & $=8.716$ & IBI (India) & $=4.260$ \\
\hline & JIF & $=1.500$ & SJIF (Morocco & $=5.667$ & OAJI (USA) & $=0.350$ \\
\hline
\end{tabular}

significance due to budgetary and private funds, to commercial banks government and community-based guarantees, and take measures to minimize the risks faced by investors, in particular due to the allocation of them between government, investment and insurance organizations. 1. Corporations and corporations have the opportunity to invest in investment through the systematic use of investment portfolio diversification methods, transfer of savings and resources of legal and private entities to investment resources of production, as well as to the development of new techniques and technologies. can be shaped.
In sum, improving the methodology of econometric modeling of intra-sectoral investment attraction to the economy ensures the proper distribution of investments in the conditions of uncertainty, avoiding unnecessary maintenance of deficit and excessive funds. Also, improving the methodology of econometric modeling of intersectoral investment in research has identified the risks and threats to the effective use of distributed investment, the sustainable growth of the sector's operations, the achievement of global competitiveness, and the deep and comprehensive analysis of factors affecting investment efficiency, the ability to determine the.

\section{References:}

1. Chernov, V. G. (2007). Model' podderzhki prinyatiya resheniy $\mathrm{V}$ investitsial'noy deyatel'nosti na osnove apparata nechetkix mnezhestv. (p.313). Moscow: Goryachaya line Telecom.

2. Berezhnaya, E. V., \& Berezhnoy, V. I. (2005). Mathematical methods and modeling economical systems. Moscow: F i S.

3. Aghion, P., Bloom, N., Blundell, R., Griffith, R., \& Howitt, P. (2005). Competition and nnovation: an inverted-U relationship. $Q . J$. Econ., 120 (2), pp. 701-728.

4. Bai, J., Philippon, T., Savov, A. (2016). Have financial markets become more informative? $J$. Financial Econ., 122 (3), pp. 625-654.

5. Bakke, T.-E., \& Whited, T. M. (2010). Which firms follow the market? An analysis of corporate investment decisions. Rev. Financial Stud., 23 (5), pp. 1941-1980.

6. Chen, Q., Goldstein, I., Jiang, W. (2007). Price informativeness and investment sensitivity to stock price. Rev. Financial Stud., 20 (3), pp. 619650.

7. Dow, J., Goldstein, I., \& Guembel, A. (2017). Incentives for information generation in markets where prices affect real investment. J. Eur. Econ. Assoc., 15 (4), pp. 877-909.
8. Maddison, D. J. (2006). Environmental Kuznets curves: a spatial econometric approach. $J$. Environ. Econ. Manag., 51, pp. 218-230.

9. Jacques, R. (2008). Kelly Calculator Investment Tool. Archived from the original on 2012-03-20.

10. Tursunov, B. O. (2017). Osnovnye napravleniya podderzhki malogo biznesa $\mathrm{v}$ Uzbekistane I zarubezhnyy opyt razvitiya predprinimatel"stva. Audit, № 6, pp. 34-38.

11. Ibragimov, I. U., \& Tursunov, B. O. (2017). Enhancement the mechanism of analyzing of the methodological principles for the development and improvement of methods of assessment. Audit, № 4, pp. 11-13.

12. Kasymov, S. S., Tursunov, B. O., \& Karimov, B. A. (2017). Metody otsenki ekonomicheskoy nadezhnosti tekstil"nogo predpriyatiya $v$ usloviyakh rynochnoy ekonomiki. V sbornike: Teoriya i praktika organizatsii promyshlennogo proizvodstva. Effektivnost' organizatsii i upravleniya promyshlennymi predpriyatiyami: problemy i puti resheniya Materialy Mezhdunarodnoy nauchno-prakticheskoy konferentsii. Voronezhskiy gosudarstvennyy tekhnicheskiy universitet. pp. 139-144.

13. (n.d.). Information from the State Committee on Statistics of the Republic of Uzbekistan (20002017). 